\title{
концепты
}

DOI: 10.30727/0235-1188-2020-63-12-68-80

Original research paper

Оригинальная исследовательская статья

\section{The Concept and Formula of Happiness: Historical and Contemporary Criteria}

\author{
G.I. Kolesnikova \\ M.I. Tugan-Baranovsky Donetsk National University \\ of Economics and Trade, Donetsk
}

\begin{abstract}
The article presents a historical and philosophical analysis of happiness as a socio-cultural phenomenon, considers the proposed criteria and components of the state of happiness as well as proposes the author's integrative definition of happiness. The relevance of this study is determined by the importance of the actual humanitarian indicators in assessing socio-political progress. As a result of the analysis of how the concept of happiness was historically formed and developed, it was shown that (a) the concept of happiness became widespread in the humanitarian discourse relatively late, (b) its predecessors are the ancient Greek concepts of agathon (the good) and eudaimonia (welfare, prosperity, supreme good), (c) in Western European philosophy, the understanding of good is contradictory and includes a wide range of meanings, from utilitarian to axiological, (d) the content of the concept of happiness includes two aspects: one is in the person's power and the other is determined by external factors. The article analyzes modern theories of happiness and feelings of life satisfaction as well as scientific studies of the components of the state of happiness. As a result of the analysis of these approaches, it is shown that in most modern studies, the emphasis in understanding happiness is placed on either socio-biological or socioeconomic factors. The author examines the criteria for the state of happiness. The author quotes other researchers and proposes certain steps as an algorithm for determining happiness, i.e., a formula for happiness. The importance of harmony of the following components of the human personality and life is substantiated: the belief system (and living in accordance with one's beliefs), abilities (and the possibility of their implementation in professional, cognitive activity), geographical location of residence, as well as social circle (and the balance of socio-psychological proximity and distancing).
\end{abstract}


Keywords: ethics, the good, well-being, satisfaction, harmony, personality, society, human capital.

Galina I. Kolesnikova - D.Sc. in Philosophy, Professor, Department Philosophy, M.I. Tugan-Baranovsky Donetsk National University of Economics and Trade.

galina_ivanovna@kolesnikova.red

http://orcid.org/0000-0002-4760-9839

For citation: Kolesnikova G.I. (2020) The Concept and Formula of Happiness: Historical and Contemporary Criteria. Russian Journal of Philosophical Sciences = Filosofskie nauki. Vol. 63, no. 12, pp. 68-80.

DOI: 10.30727/0235-1188-2020-63-12-68-80

\section{Понятие и формула счастья: исторические и современные критерии}

\section{Г.И. Колесникова}

Донецкий национальный университет экономики и торговли имени Михаила Туган-Барановского, Донецк

\section{Аннотация}

В статье представлен историко-философский анализ понятия счастья как социокультурного феномена. Рассмотрены критерии и составляющие состояния счастья, сформулированные исследователями разных эпох, а также предложено авторское интегративное определение данного понятия. Актуальность настоящего исследования обусловлена важностью собственно гуманитарных показателей при оценке социально-политического прогресса. В процессе анализа показано, как исторически формировалось и развивалось понятие «счастье». Во-первых, по утверждению автора, оно поздно получило распространение в гуманитарном дискурсе. Во-вторых, его предшественниками в философской литературе выступают древнегреческие понятия $\dot{\alpha} \gamma \alpha \theta o ́ v$ (благо) и $\varepsilon \dot{v} \delta \alpha \imath \mu o v i ́ \alpha$ (процветание, благополучие, высшее благо). В-третьих, в западноевропейской философии понимание блага противоречиво и включает в себя широкий диапазон значений от утилитарного до аксиологического. В-четвертых, содержательное наполнение понятия «счастье» характеризуют два аспекта: находящееся во власти самой личности и определяемое внешними факторами. В статье изложены и проанализированы современные теории счастья и чувства удовлетворенности жизни, научные исследования слагаемых состояния счастья. В результате анализа этих подходов сформулирован вывод о том, что сегодня в большинстве исследова- 
ний акцент в понимании счастья сделан на социально-биологических либо социально-экономических факторах. Представлены предложения ряда исследователей и автора статьи, которые могут выступать в качестве алгоритма определения счастья, т.е. формулы счастья. Обоснована значимость гармонии следующих составляющих человеческой личности и жизни: системы убеждений (и жизни в соответствии со своими убеждениями), способностей (и возможностей их реализации в профессиональной, познавательной деятельности), географического места проживания, круга общения (а также баланса социальнопсихологической близости и дистанцирования).

Ключевые слова: этика, благо, благополучие, удовлетворение, гармония, личность, общество, человеческий капитал.

Колесникова Галина Ивановна - доктор философских наук, профессор, профессор кафедры философии Донецкого национального университета экономики и торговли имени Михаила ТуганБарановского.

galina_ivanovna@kolesnikova.red

http://orcid.org/0000-0002-4760-9839

Для цитирования: Колесникова Г.И. Понятие и формула счастья: исторические и современные критерии // Философские науки. 2020. T. 63. № 12. C. $68-80$. DOI: 10.30727/0235-1188-2020-63-12-68-80

\section{Introduction}

In modern political and social discourse, protection of individual rights and freedoms and development of human capital are recognized as major goals. Thus, the constitutional obligation of state authorities is the recognition, observance, and protection of the rights and freedoms of the individual, "since human resource is the main resource of the State, and the well-being of the country ultimately depends on the development of each individual" [Kolesnikova 2017, 102]. But at the same time, the criteria for such development are mainly reduced to socio-economic indicators, which is often criticized as lacking proper humanitarian and anthropological criteria for assessing the conditions for personality development.

Therefore, it is important to determine the components of an individual's happiness in order to form a methodology that allows, among other things, to adequately assess socio-economic policy both within the country and in the international arena. An indirect confirmation of this thesis can be the fact that in Siberia, Tomsk State University is planning to create the first international laboratory in Russia to study 


\section{G.I. KOLESNIKOVA. Concept and Formula of Happiness: Historical and...}

the criteria of happiness, and in the Kingdom of Bhutan there is even an Institute of Happiness, on the basis of which the concept of Gross National Happiness was created, which, along with GDP, is adopted in the kingdom into account when studying the living standards of the population [Verma 2019].

However, before determining the criteria and components of happiness as a sociocultural phenomenon, it is necessary to study the history and etymology of this concept and to analyze the previously proposed "objective" indicators and theories of happiness.

\section{History and etymology of the concept of happiness}

The concept of happiness in Western philosophy became widespread relatively late. In Classical antiquity, the category of good was used as a concept denoting the quality to which a person strives. The use of the word "happiness" found in translations of ancient Greek texts is rather casual, due to the paradoxes of translation (like the original word "fruit" from the Hebrew Bible became associated with "apple" in Latin tradition). At some later point, there was first a confusion of, in our opinion, completely different concepts of "good" and "happiness," and then almost complete elimination of the category of good from humanitarian discourse.

The ancient Greek language had two concepts: $\dot{\alpha} \gamma \alpha \theta \dot{v} v$ - "good"

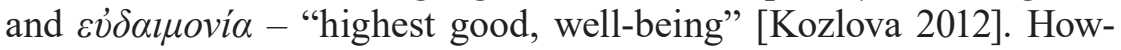
ever, in the ancient Greek tradition, nearly every philosopher filled the category of "good" with his own meaning. For Pythagoras, good consists "in knowledge of the perfection of the numbers of the soul" [Fideler 1987, 33]; for Socrates (in Plato's dialogues), "everything that is connected with intelligence, prudence and understanding belongs to good" [Mesyats 2012, 324]; for Aristotle, the good is expressed in moral actions, identified "with one or another form of virtuous activity" [Seregin 2017, 77]. But despite the disagreements, the majority of philosophers agreed that only an educated and wise person can have a proper understanding of good (that is, the desire for good is the result of a combination of wisdom and knowledge). Moreover, where Plato writes about the identity of the concepts of the One and the Good, then

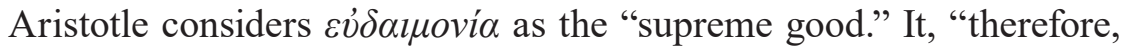
being found to be something final and self-sufficient, is the End at which all actions aim" (EN. 1097b20).

The words $\varepsilon \dot{v} \delta \alpha \mu$ oví $\alpha$ consists of two roots: $\varepsilon \tilde{v}$ (good) and $\delta \alpha i \mu \omega v$ (deity, spiritual being). Thus, it literally means the benevolence of 
gods perceived as a "divine fate," not in the utilitarian sense, but as a divine part of the soul, which makes a person capable of contemplation and wisdom, leading to the highest good, the divine fate. And here it is important to dwell on the second component of this word $\delta \alpha i \mu \omega v$. "Homer uses the word $\delta \alpha i \mu \omega v$ not only to refer to the acting agent directly related to fate but also to give a vague definition of deity in general. Back in 1904, Danish researcher O. Jørgensen, comparing the special features of nominations of the gods by Homer in cases when epic heroes speak and when the poet himself narrates the story of events, discovered that when the epic heroes attributed something that suddenly happened and was beyond their control to a superhuman force, the poet put into their mouths such vague names of this force as $\theta \varepsilon o ́ \varsigma$ ('god') or $\delta \alpha i \mu \omega v$ ('demon,' 'genius'). And the poet himself explains such events by an intervention of a certain god (see, for example: Iliad, XV, 460-473)" [Goran 1990, 123-124]. Thus, V.P. Goran continues, "a genius gets a man by lot at the moment the man is born [...]. According to traditional beliefs, the lots distributed by Lachesis can be called individual paths of life, fates, destinies. [...] But he [Plato] still left these samples in Lachesis' lap, which we see as one of relics of traditional ideas about the role of this goddess. Also, relics of ideas about the old role of Lachesis are expressed in the concept that once the soul selects a sample of life for itself, and hence a relevant genius, it approaches Lachesis in the manner determined by lot, who sends this genius with the man as his guardian and guarantor of fulfilling his choice (cf.: Plato. Republic, $620 \mathrm{~d}-\mathrm{e}$ )" [Goran 1990, 162]. In other words, daimon (close to the concept of genius in the Roman civilization) is a divine spark (one of the most important concepts in Socrates' teaching) serving as a guide (inner voice) directing the man to fulfil his destiny (fate), but only if the man "listens" to his daimon. Probably, the famous saying of the Stoic thinker Cleanthes, cited by Seneca, is based on these ideas about the relationship between fate and a man: "Fate leads the willing and drags along the reluctant." The most complete definition of $\varepsilon \dot{\delta} \delta \alpha \mu$ oví $\alpha$ as the supreme good can be found in Aristotle's work - "it is a certain kind of activity of the soul; whereas the remaining good things are either merely indispensable conditions of happiness, or are of the nature of auxiliary means, and useful instrumentally" (EN. 1099b25). In this regard, it is important to pay attention to the activity aspect contained in the Aristotelian definition of the supreme good, as well as the correlation of the activity itself with goal-setting. 


\section{G.I. KOLESNIKOVA. Concept and Formula of Happiness: Historical and...}

Thus, in the ancient Greek ethics, the supreme good - $\varepsilon \dot{v} \delta \alpha \mu$ oví $\alpha-$ includes two aspects: subjective (the person himself defines the degree of his satisfaction with life) and objective - the existence of external goods (e.g., nice living conditions). However, almost all philosophers of ancient Greece agree that neither wealth nor luxury corrupts a man, in contrast to the Roman tradition, which used more utilitarian term fortuna with meanings "luck," "fate," "prosperity" (with plural form fortunae meaning "posessions," "property"). Being a calque of the name of the goddess of fate - Fortuna, it personifies the divine mercy, granted only to the worthy. That is, the perception of good/happiness as a category was practical and was perceived as welfare and the possibility to satisfy one's needs. Besides, there were ecstatic practices of union with a deity (widespread mainly among lower classes), leading the participants to feeling happy and blessed [Inge 1921, 49]. Thus, in the ancient Greek tradition of understanding the "supreme good," we find a harmonious combination of hedonistic and practical aspects $^{1}$.

With the dominance of Christian ideology, the understanding of good / happiness changes dramatically, coming to mean, above all, humility and subsequent reward or retribution: the Fathers of the Church rearranged ideas of ancient philosophers based on the principle of theism, attributing the quality of the supreme good-summum bonum - to God, both as the source and the ultimate goal of human life.

In the philosophy of Modern Times, emphasis in classifying something as good was transferred to the subject (Hobbes, Spinoza), and the good was construed mostly in the utilitarian sense. However, by the middle of the $19^{\text {th }}$ century, the notion "good" was replaced by the notion "value" (H. Rickert), and the good began to be perceived exclusively in the sense of "welfare." The issue of relationship between the good and value is still debatable. Thus, at one time, the Baden school of Neo-Kantianism preferred to oppose good and values, defining "good" as an abstract sample, similar to the Plato's ideas. In modern philosophy, the concept of good was extensevily developed in the works of G.E. Moore [Moore 1903], M. Scheler [Scheler 1916], N. Hartmann [Hartmann 1926].

1 Partially similar understanding can be found in the ideas of Abraham Maslow, who distinguishes between higher and basic needs, saying that higher ones cannot be formed if basic ones remain unsatisfied; although he also stipulates that history knows men focused on higher needs, while their basic needs were barely satisfied [Maslow 1943]. 
In the late $19^{\text {th }}$ and early $20^{\text {th }}$ centuries, representatives of the Russian religious philosophy criticized the idea of happiness as the main principle of human life. Vladimir Solovyov [Solovyov 1989] argued that the concept of happiness had no moral nature and could not serve as the basis of ethics. Vasily Rozanov [Rozanov 1994] and Nikolai Berdyaev [Berdyaev 1937] opposed the pursuit of happiness to pursuit of meaning, as a focus on something valuable in the world.

Thus, in the philosophy of the $20^{\text {th }}$ and $21^{\text {st }}$ centuries, the study of the good was conducted along the following lines: is the good an objective quality or a subjective evaluation? [Lambert 2007]; is it possible to correlate utilitarian, hedonistic, and spiritual values to the concept of good?; does the "supreme good" exist, and if so, what is its content?; are the concept of good and the hierarchy of goods specific to the Classical antiquity relevant now? [Oishi et al. 2013].

Polish philosopher W. Tatarkiewicz in Analysis of Happiness notes that happiness "is one of the highest, if not the highest good that a person can achieve" [Tatarkiewicz 1981, 34]. Distinguishing between external and internal factors of happiness, Tatarkiewicz notes that if a favorable external circumstance "does not rely on certain mental qualities, then it will not become a factor of happiness" [Tatarkevich 1981, 154]. "Human life is a constant play of internal conditions and external circumstances of happiness, and whether happiness will be achieved largely depends on their harmonious relationship" [Tatarkevich 1981, 155].

\section{Search for "objective" indicators of happiness}

We propose to describe four main directions that researchers pursued in search of, as it seemed to them, scientific and "objectively" verifiable indicators of happiness.

(1) The theory of needs satisfaction or goal achievement theory: the state of happiness is the result of the satisfaction of needs. This approach is based on the works of A. Maslow (hierarchy of needs), K. Alderfer (ERG theory), D. McClelland (need for achievement theory).

(2) Theories of activity, theories of process: practicing an activity that you like makes you happy. Thus, happiness presupposes involvement in a process aimed at achieving an independently chosen positive goal, and one's own actions to achieve them. As noted by E. Diener, activity theories premise that "happiness is a by-product of human activity" [Diener 1984, 564]. The origins of the activity-based approach to explaining happiness are often seen in Aristotle's expression that

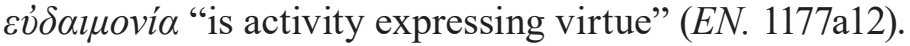


(3) Congenital predisposition theory. The level of happiness is innate. This assumption was partially confirmed in genetics. Based on processing the results obtained during the U.S. National Longitudinal Study of Adolescent Health, a correlation was found between the long allele of 5-HTTLPR gene, which is responsible for transporting of serotonin ("happiness hormone"), and life satisfaction. The long allele of 5 -HTTLPR gene was found in $20 \%$ of those who, in the course of the survey, stated that they were not satisfied with their lives, and in $35 \%$ of those who were very satisfied with their lives [De Neve 2011].

But, in our opinion, it is wrong to equate unhappiness and depression, as one can be happy, yet feel sad about the world's fates. Besides, it is possible that those people who are called depressive are not, in fact, those who think about bad things, but those who do think.

(4) Economic theory. It is close to the theory of satisfied needs, with an emphasis on the economic factor [Lavrova 2012]. In this respect, research headed by R. Veenhoven, founder of World Database of Happiness, is highly popular in the modern scientific space. Based on his concept, the level of happiness of the country's population correlates to its level of economic development. According to him, the populations of Western Europe and North America are the happiest [Veenhoven \& Vergunst 2014]. However, data from other studies contradict his conclusions: the level of happiness hardly depends on the standard of living (provided that this level does not fall below a certain minimum). And this actually confirms the Maslow's concept. For example, sociologists of the New Economics Foundation (UK) revealed the following: residents of islands in the Pacific, of Colombia, Costa Rica, Panama, Cuba, and Honduras (and other Latin American countries) have the highest index of happiness; residents of "developed" countries have low index of happiness: United Kingdom has the $108^{\text {th }}$ place, France $-129^{\text {th }}$, and the USA $-150^{\text {th }}$. However, the fact that Russia has the $172^{\text {nd }}$ and Ukraine, the $174^{\text {th }}$ place in this list suggests that the happiness index is not directly correlated to the quality of life and rather depends on other factors [Shmatova \& Morev 2015].

\section{Study of components of happiness}

There have been several attempts to create a "formula" for happiness. Some of the best known are the following.

(1) The equation for happiness by M. Seligman: $\mathrm{S}+\mathrm{C}+\mathrm{V}=$ Happiness, where $\mathrm{S}$ is (genetically predetermined) set range level of happiness (accounts for about $50 \%$ of score on happiness tests); $\mathrm{C}$ is 
circumstances of life (family, children, religion, daily activities; share from $8 \%$ to $15 \%$ ); V represents factors under voluntary control, i.e., conscious, intentional, and effort demanding actions (share - from $35 \%$ to $42 \%$ ) [Seligman 2002, $45 \mathrm{ff}$.].

(2) In 2003, British psychologists proposed the following formula of happiness: Happiness $=\mathrm{P}+(5 \times \mathrm{E})+(3 \times \mathrm{H})$, where $\mathrm{P}$ stands for personality characteristics (outlook on life, beliefs, etc.), E stands for existence needs (financial stability, health, etc.); and $\mathrm{H}$ represents higher order needs (self-esteem, self-realization, and ambitions) [Annas 2004, 44].

(3) A group of scholars at University College London have conducted research on momentary subjective well-being [Rutledge et al. 2014; Rutledge et al. 2016]. According to the results of an experiment on volunteers who were asked to play a game with a monetary gain, the researchers proposed a complex formula for the feeling of satisfaction that relates the received reward, the expected reward, and the difference between one's own winnings and the partner's winnings, as well as the person's inclination to envy (if the partner's gain is greater than his own) or guilt (when his own gain is greater than that of the partner). The subjective feeling of satisfaction was the higher when the distribution of gains was more equal and the person was less inclined to envy and feelings of guilt. Thus, it provided "quantitative confirmation that an individual's subjective reports of momentary well-being in a social context reflect not only how well things are going relative to expectations, but also how things are going relative to other people, even when outcomes for others are both independent from, and irrelevant to, the subjects' own earnings" [Rutledge et al. 2016, 5].

Thus, in understanding happiness, most modern studies focus on either socio-biological or socio-economic components, disregarding spiritual and mental aspects.

However, the reduction of happiness to a formula inevitably simplifies the understanding of happiness. At one time, the Russian thinker N.K. Mikhailovsky (1842-1904) noted that a person is too individual to be determined through statistical or mathematical data, and, therefore, there is not and cannot be a single happiness for everyone. Striving for personal happiness is natural and it is based on autonomy and freedom, as well as on a gradual change of impressions in the constant striving to develop and expand the range of one's life [Vyazinkin 2012]. It is also necessary to highlight the spiritual tradition of the East, in the context of which happiness is understood as the natural state of a person, but its fulfillment is hindered by delusions, and the overcoming of 


\section{G.I. KOLESNIKOVA. Concept and Formula of Happiness: Historical and...}

such delusions is the Path, following which happiness is not so much acquired as it is realized [Ioseliani 2014].

Therefore, we can see the juxtaposition of two approaches to understanding happiness: the individualized social/economic approach specific to the European culture, and the spiritual tradition of the East, which interprets happiness as a natural state of a human being. The Slavic tradition takes up the middle position. Whereas the European tradition of happiness relates to an external position with regard to a person, the Slavic tradition relates to an internal one, and the Eastern tradition of happiness, in our view, is a meta-position.

\section{Conclusion}

In our opinion, a harmonic unity of corporal/material/social and spiritual/emotional aspects in a person creates the uniqueness of human existence.

In other words, happiness is the state of harmony. The harmony results from the unity of the subjective and the objective; the subjective is understood as the system of beliefs and aspirations of a person, while the objective is a set of person's living conditions created through his expedient activity.

In our opinion, we can single out four basic components in the unity of the ideal (the intrinsic) and material (the extrinsic) as a result of realization, manifestation, and exteriorization of the internal ideal in the world around: (a) belief systems (as well as loyalty to own beliefs and life in accordance with these beliefs; the result of the search for an answer to the question "why?"), (b) abilities (as well as the possibility of their implementation in professional and cognitive activities; questions "what?" and "how?"), (c) the geographical location of residence (the question "where?"), (d) social circle, milieu (as well as the balance of socio-psychological closeness and distance; the question "with whom?").

Thus, happiness is the harmony of triune: of person with the Self, of the Self with the world, and of the world with the Self (i.e., the unity of internal harmony, of subjective perception of external harmony, and of objective conditions of external harmony).

We have not singled out any personal qualities that contribute to the achievement of happiness because we believe that one can a priori think about happiness in one's own human way only in relation to a person guided by rational aesthetic principles, an educated and civilized person. (However, we do not equate the notion of an "edu- 
cated and civilized person" to a "university degree holder" or a "senior position holder" because in the modern world, unfortunately, these do not coincide.)

The topics of upbringing and teaching of a person guided by the rational aesthetic principle, as well as factors that positively or negatively impact this process [Kolesnikova 2018; Shakbanova, Kolesnikova et al. 2019; Kolesnikova 2020], have been developed by the author of the article in other papers.

\section{REFERENCES}

Annas J. (2004) Happiness as Achievement. Daedalus. Vol. 133, no. 2, pp. 44-51.

Berdyaev N.A. (1937) The Destiny of Man. London: G. Bless.

De Neve J.-E. (2011) Functional Polymorphism (5-HTTLPR) in the Serotonin Transporter Gene is Associated with Subjective Well-Being: Evidence from a US Nationally Representative Sample. Journal of Human Genetics. Vol. 56, no. 6, pp. 456-459.

Diener E. (1984) Subjective Well-Being. Psychological Bulletin. Vol. 95, no. 3, pp. 542-575.

Fideler D.R. (1987) Introduction. In: Guthrie K.S. (Comp. \& Trans.) The Pythagorean Sourcebook and Library (pp. 19-54). Grand Rapids, MI: Phanes Press.

Goran V.P. (1990) Ancient Greek Mythologeme of Fate. Novosibirsk: Nauka, Siberian Branch (in Russian).

Hartmann N. (1926) Ethik. Berlin: de Gruyter (in German).

Inge W.R. (1921) Religion. In: Livingstone R.W. (Ed.) The Legacy of Greece (pp. 25-56). Oxford: Clarendon Press.

Ioseliani A.D. (2014) Ecological Consciousness and Religious Values in the Scriptures of the East. Filsofia i obshchestvo. No. 3, pp. 104-118 (in Russian).

Kolesnikova G.I. (2017) Social Policy of Russia: The Concept of Personality Development in the $21^{\text {st }}$ Century. Mezhdunarodny nauchny zhurnal. Series: Humanities. No. 3. pp. 102-107.

Kolesnikova G.I. (2018) The Conception of Personality Development: Social and Economic Mechanisms. In: Bodrunov S.D. (Ed.) Forsight "Russia": New Industrial Society. Reset: Collection of Reports of the St. Petersburg International Economic Congress (SPEC-2017) (Vol. 2, pp. 518-526). Saint Petersburg: Institute for New Industrial Development (in Russian). 
Kolesnikova G.I. (2020) Paradoxes of Comprehension of the Concepts "the Man" and "a Man" in the History of Civilization. Arkhont. Vol. 6, pp. 13-21 (in Russian).

Kozlova K.S. (2012) The Category of Good: From Philosophical and Ethical to Economic and Political and Legal Meanings. Omsk Scientific Bulletin. No. 3, pp. 99-103 (in Russian).

Lambert C. (2007) The Science of Happiness. Harvard Magazine. No. 1, pp. 26-30, 94. Retrieved from https://www.harvardmagazine.com/2007/01/ the-science-of-happiness.html

Lavrova N.A. (2012) The Economy of Happiness. Bulletin of the Saratov State Social and Economic University. No. 4, pp. 31-35.

Maslow A.H. (1943) A Theory of Human Motivation. Psychological Review. Vol. 50, no. 4, pp. 370-396.

Mesyats S.V. (2012) Plato's Philebus on the One, Many and the Middle (a Note on 14c-18d). Schole. Vol. 6. no. 2, pp. 323-339 (in Russian).

Moore G.E. (1903) Principia Ethica. Cambridge: Cambridge Univesity Press.

Oishi S., Graham J., Kesebir S., \& Galinha I.C. (2013) Concepts of Happiness Across Time and Cultures. Personality and Social Psychology Bulletin. Vol 39, no. 5, pp. 559-577.

Rozanov V.V. (1994) The Purpose of Human Life. Moscow: ProgressKul'tura (in Russian).

Rutledge R.B., Skandali N., Dayan P., \& Dolan R.J. (2014) A Computational and Neural Model of Momentary Subjective Well-Being. Proceedings of the National Academy of Sciences. Vol. 111, no. 33, pp. 12252-12257.

Rutledge R.B., De Berker A.O., Espenhahn S., Dayan P., \& Dolan R.J. (2016) The Social Contingency of Momentary Subjective Well-Being. Nature Communications. Vol. 7, article no. 11825.

Scheler M. (1916) Der Formalismus in der Ethik und die materiale Wertethik: neuer Versuch der Grundlegung eines ethischen Personalismus. Halle (Saale): M. Niemeyer (in German).

Seligman M.E.P. (2002) Authentic Happiness: Using the New Positive Psychology to Realize Your Potential for Lasting Fulfillment. New York: Atria.

Seregin A.V. (2017) Instrumentalism and Inclusivism in Aristotle's Interpretation of "External" Goods (on EN 1099a24-b7). Ethical Thought. Vol. 17, no. 2, pp. 73-90 (in Russian).

Shakhbanova M.M., Kolesnikova G.I., Gryshai V.N., Abramov M.A., Skvortsov D.V., Kurnosenko. A.A., \& Korsakov A.N. Factors of Intolerance 
Formation in Modern Russian Society. Dilemas contemporáneos: Educación, Política y Valores. Vol. 6, no. S3, article no. 29.

Shmatova Y.E. \& Morev M.V. (2015) Measuring the Level of Happiness: Review of Russian and Foreign Studies. Ekonomicheskie $i$ sotsial'nye peremeny: fakty, tendentsii, prognoz. No. 3, pp. 141-162 (in Russian)

Solovyov V.S. (1989) Russian national ideal (on the N.Ya. Grott's Article in Voprosy filosofii i psikhologii). In: Solovyov V.S. Works in 2 Vols. (Vol. 2 , pp. 286-295). Moscow: Pravda (in Russian).

Tatarkiewicz W. (1981) On Happiness and Perfection of Man. Moscow: Progress (Russian translation).

Vyazinkin A.Y. (2012) Personal Happiness and the "Formula for life" as the Basic Concepts of N.K. Mikhailovsky's Theory of Struggle for Individuality. Tomsk State University Journal. No. 4, pp. 287-282.

Veenhoven R. \& Vergunst F. (2014) The Easterlin Illusion: Economic Growth Does Go with Greater Happiness. International Journal of Happiness and Development. Vol. 1, no. 4, pp. 311-343.

Verma R. (2019) The Eight Manifestations of GNH: Multiple Meanings of a Development Alternative. Journal of Bhutan Studies. Vol. 41, pp. 1-31. 